\title{
Glacier advance, ice-marginal lakes and routing of meltwater and sediment: Russell Glacier, Greenland
}

\author{
Peter G. Knight, ${ }^{1}$ Righard I. Waller, ${ }^{2}$ Carrie J. Patterson, ${ }^{3}$ Alison P. Jones, ${ }^{4}$ Zoe P. Robinson ${ }^{1}$ \\ ${ }^{1}$ School of Earth Sciences and Geography, Keele University, Keele, Staffordshire ST 5 5BG, England \\ ${ }^{2}$ School of Earth and Environmental Sciences, University of Greenwich, Chatham Maritime, Kent ME4 4TB, England \\ ${ }^{3}$ Minnesota Geological Survey/University of Minnesota, 2642 University Ave., St Paul, Minnesota 55114 -1057, U.S.A. \\ ${ }^{4}$ Department of Geography, University of Liverpool, Liverpool L69 3BX, England
}

\begin{abstract}
The ice-sheet margin at Russell Glacier, West Greenland, advanced $\sim 7 \mathrm{~m} \mathrm{a}^{-1}$ between 1968 and 1999. As the ice advanced over moraine ridges, small changes in position caused major changes in the routing of proglacial water and sediment. These included changes in the distribution of ice-marginal lakes, in the periodic drainage of icedammed lakes, in the routing and sediment content of meltwater draining into the proglacial zone, and in the release of sediment from the moraines by erosion and mass movements. Proglacial hydrology and sediment flux appear to be controlled not simply by glacier mass balance, but by evolving ice-marginal geomorphology, which must be accounted for in palaeoenvironmental interpretation of proglacial sediments.
\end{abstract}

\section{INTRODUCTION}

Ice-marginal lakes at Russell Glacier, part of a lobe of the West Greenland ice sheet (Fig. 1), are well documented (e.g. Sugden and others, 1985; Gordon, 1986; Russell and de Jong, 1988; Scholz and others, 1988; Russell, 1989; Russell and others, 1990; Knight and Russell, 1993). Their characteristics depend primarily on the position of the ice margin relative to surrounding topography, and their behaviour (stability or periodic drainage) strongly influences proglacial hydrology and sediment routing. This paper reports how recent changes in the position of the ice margin have had a disproportionate effect on the proglacial area through their influence on ice-marginal lakes and meltwater routing.
Locations of sites mentioned in the text are shown in Figures 1 and 2. Table 1 summarizes details of the lakes.

\section{OBSERVATIONS}

\section{Ice margin}

The ice margin in this area was in recession for about 50 years after 1920, but has readvanced during the past three decades (Weidick, 1991; Weidick and others, 1992; Van Tatenhove and others, 1995), consistent with observed present-day thickening of the western sector of the ice sheet (Thomas and others, 1998). Russell Glacier reflects these regional trends. Aerial photographs from 1968 and 1985, and field

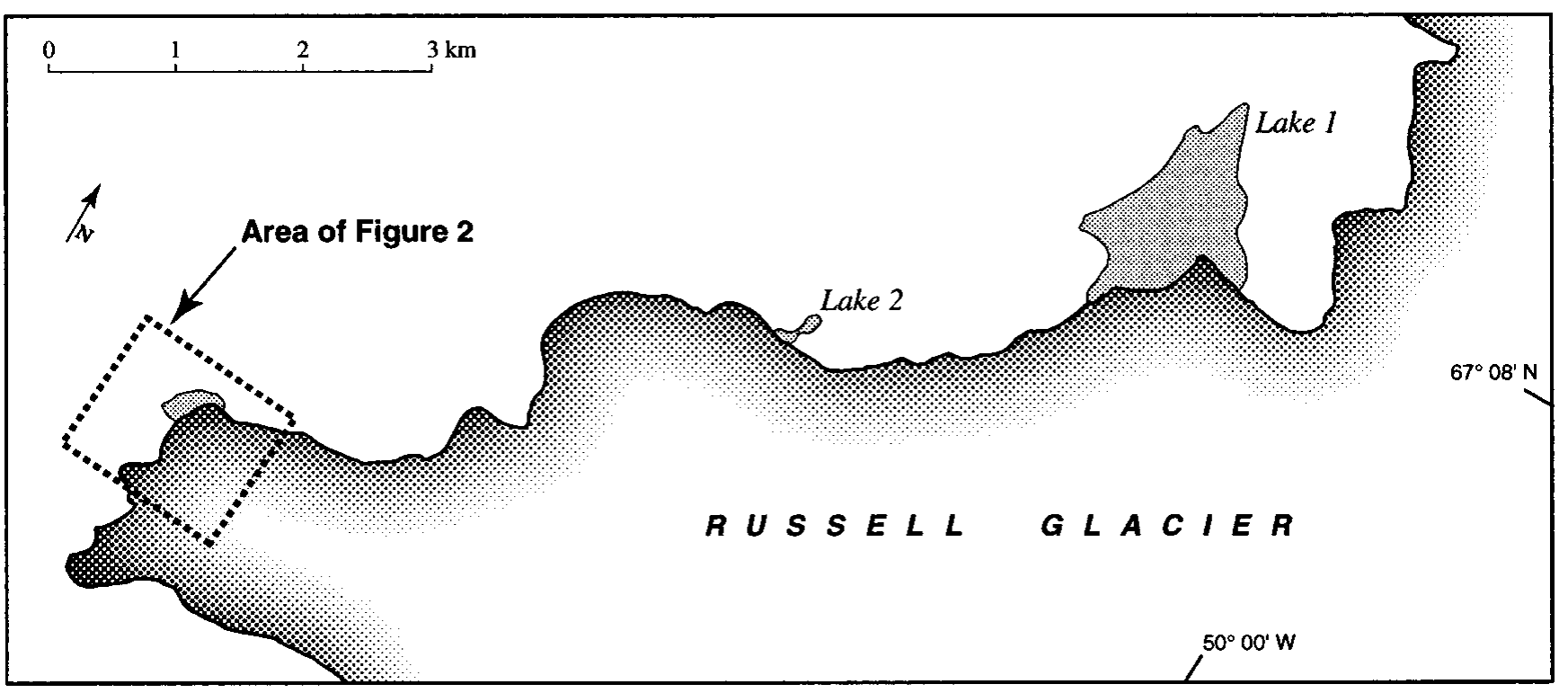

Fig. 1. The northern lateral margin and snout of Russell Glacier, indicating the positions of sites referred to in the text and the location of the area of Figure 2. 


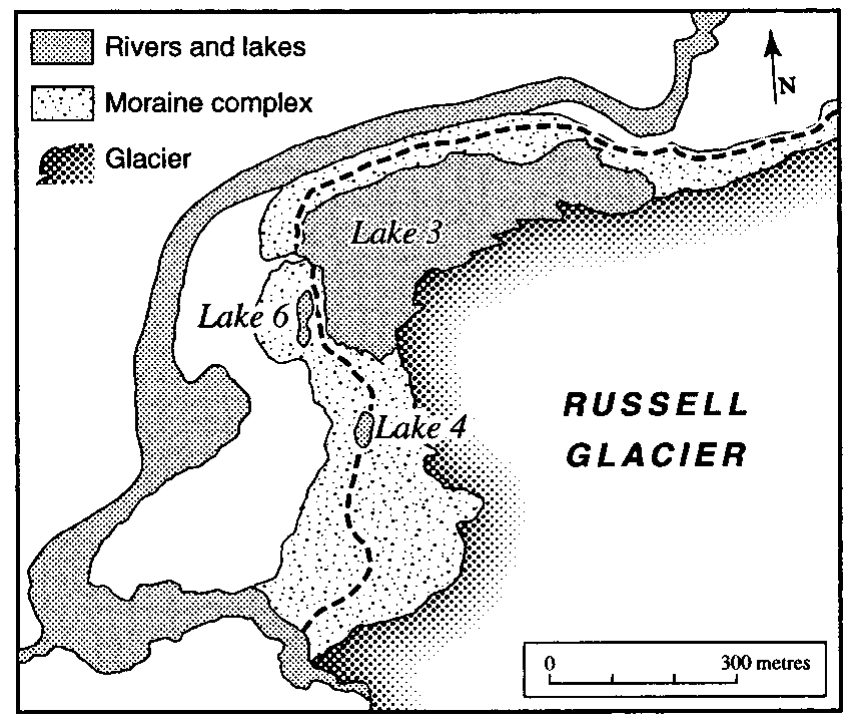

Fig. 2. The northern part of the snout of Russell Glacier, showing the position of sites referred to in the text and the position of the ice margin in 1968 (solid line) and 1999 (dashed line).

observations from 1984 to 1999, indicate that most of the margin advanced $30-70 \mathrm{~m}$ in 30 years, and parts of the northern terminus advanced $>210 \mathrm{~m}$ (Fig. 2).

Until 1985, the margin lay within a complex moraine $35 \mathrm{~m}$ high, comprising diamictons of gravels/boulders in a sand/silt matrix, thin beds of sand and granules, and intramoraine lake sediments with bedsets of clay, silt and fine sand up to $0.7 \mathrm{~m}$ thick. Sediment production per linear metre of the ice margin was $\sim 24 \mathrm{~m}^{3} \mathrm{a}^{-1}$, of which $60 \%$ was silt and clay, and $40 \%$ sand, gravel and boulders. Meltwater flowed laterally through intra-moraine channels, reaching the proglacial area only through breaches in the moraine. Water and debris released from the ice was therefore partially trapped in basins within the moraine or between the moraine and the ice. Measurements of stream loads at moraine breaches indicated that only $20 \%$ of the glacier's silt and clay output was released to the proglacial zone.

During 1985-99, 30\% of the margin advanced over the moraine crest, destabilizing the moraine and routing meltwater from the glacier surface and the debris-rich basal ice directly onto its distal face. Debris from the ice, and from gullying and debris flowage in the moraine, was then supplied directly into the proglacial river. Debris-flow lobes and steep boulder and gravel fans formed at the foot of gullies in the moraine, grading into low-angle fans of finely bedded sand and silt truncated by the river.

Seasonal changes in glacier thickness and position also af-

Table 1. Characteristics of the lakes discussed in the text

\begin{tabular}{|c|c|c|c|}
\hline Lake No. & Area & Basin type & Status (September 1999) \\
\hline
\end{tabular}

$17.1 \times 10^{5}$ Ice-hillside. Periodically draining Stable. Full to until 1987 capacity

$2 \quad 2.3 \times 10^{4}$ Ice-hillside. Periodically draining Empty. Drained 1999

$39.5 \times 10^{4}$ Ice-moraine. Stable Overridden by glacier

$45 \times 10^{2}$ Ice-moraine. Seasonally draining Newly created since

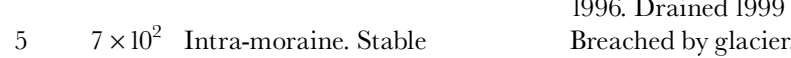
Drained and incised fected ice-marginal drainage. Ice thickness fluctuated by an average of $2 \mathrm{ma}^{-1}$, and the margin advanced by up to $15 \mathrm{~m}$ between September and April each year, and receded by a smaller amount in response to summer ablation. This created prominent erosional trimlines at the seasonal maximum position, superimposed dump-push moraine ridges onto the pre-existing moraine, and influenced both the formation and drainage of seasonal ice-dammed lakes within the moraine complex and the periodic drainage of perennial lakes.

\section{Ice-marginal lakes}

Until 1987, lake 1 (Fig. 1; Table 1) periodically drained through subglacial tunnels, causing geomorphologically and glaciologically significant jökulhlaups (Sugden and others, 1985; Gordon, 1986; Russell and de Jong, 1988; Scholz and others, 1988; Russell, 1989). Drainage events ceased after 1987, because the ice advanced to a point where the maximum lake depth was insufficient to cause flotation. In 1999 the ice margin had advanced $<10 \mathrm{~m}$ since 1994 . The lake was at maximum capacity, overflowing through a bedrock col. There were no signs of recent subglacial drainage. The channel previously created by the floodwater emerging down-glacier was no longer well defined. The delta created by the floodwater was still prominent, but dissected by meltwater discharge since the last flood. The lake is stable, and further sudden drainage events are unlikely until the ice recedes.

Lake 2 (Fig. 1; Table 1) drains periodically via an ice tunnel at the deepest part of its basin (Knight and Russell, 1993). In 1999 the position of the margin was unchanged since 1991. Fresh shorelines around the basin's perimeter indicated recent drainage from maximum capacity through a near-semicircular subglacial tunnel $7 \mathrm{~m}$ high and $10 \mathrm{~m}$ wide. This lake continues to be unstable.

Lake 3 (Fig. 2; Table 1) diminished as the glacier advanced, and by 1999 the lake basin was completely overrun. The elimination of lake 3 removed a sediment trap of $3 \times 10^{5} \mathrm{~m}^{3}$ from the front of the glacier, and the main stream draining the northern terminus was subsequently supplied directly by turbid water emerging from the debris-rich basal ice and from the debris-covered supraglacial zone. During low flow in mid-September, the stream water contained $20 \mathrm{~g} \mathrm{~L}^{-1}$ of sediment in transport, ranging from clay to coarse sand $(<2 \mathrm{~mm})$. Characteristic sediment load in outflow from lake 3 was previously an order of magnitude less, and comprised only clay and silt $(<0.06 \mathrm{~mm})$.

Lake 4 (Fig. 2; Table 1) formed between the ice and the moraine in 1999 when the glacier was at its early-season maximum. It drained between ice and moraine during the margin's summer recession with a significant geomorphic impact, although its volume $\left(750 \mathrm{~m}^{3}\right)$ was trivial. Drainage was routed between moraine ridges parallel to the ice margin for $80 \mathrm{~m}$ before passing through a moraine breach into the proglacial area. The drainage occurred abruptly, leaving no intermediate shorelines, and with the topset-foreset contact of a debris-fan prograding into the lake maintaining a constant elevation. A gully with an average cross-sectional area of $2 \mathrm{~m}^{2}$ was eroded, discharging $>160 \mathrm{~m}^{3}$ of material into the proglacial area. The moraine breach was enlarged, and a steep boulder-fan was deposited on its distal side. Rotational slips and tension cracks appeared on the distal face of the moraine behind which the lake was dammed (Fig. 3).

Drainage rerouting associated with glacier advance has destroyed several intra-moraine lakes. Until 1996, lake 5 

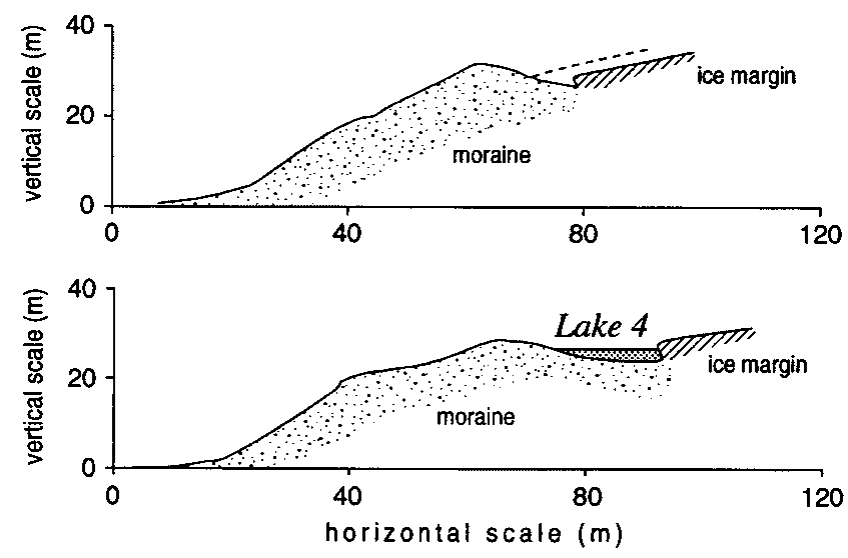

Fig. 3. Cross-sections through the moraine at the snout of Russell Glacier. The top diagram shows the position of the ice margin $10 \mathrm{~m}$ north of lake 4 in May 1999 (dashed line, based on moraine limits) and September 1999 (surveyed position). The lower diagram shows the position of lake 4 perched close to the summit of the moraine, and illustrates the slump scar on the distal face of the moraine below the lake.

(Fig. 2) was separated from the glacier and from lake 3 by a moraine ridge and was supplied entirely by meteoric and ground-water sources. In 1996 the glacier breached the basin, causing seasonal input of meltwater. By 1999 the increased water supply caused the lake to overflow its basin, eroding the overspill and causing the lake to drain completely. The lake's sediment was then incised by meltwater and discharged into the proglacial river.

As the glacier advances, more locations are becoming susceptible to falls of ice into the river that skirts its margin (Fig. 1). Russell and others (1995) described the hydrological importance of falls of ice into this river, which has achieved occasional flood discharges of $1080 \mathrm{~m}^{3} \mathrm{~s}^{-1}$ (Russell, 1989). The margin $1.5 \mathrm{~km}$ west of lake 2 now calves directly into the river channel, with the potential to cause temporary blockages throughout the melt season. Fresh till and disturbed ground on the distal side of the river indicate seasonal advances across the channel. If the ice continues to thicken or advance, water will be ponded behind the ice in its advanced spring position, causing temporary lake formation followed by abrupt drainage.

\section{DISCUSSION}

These observations indicate that, even during periods of steady advance with little long-term variability in glacier melting and sediment production, water and sediment discharge into the proglacial zone can be highly variable. Proglacial hydrology and sediment transfer are strongly influenced by varying storage potential in moraines and inter-moraine or ice-marginal channels and basins, and by periodic releases of stored material. As Russell Glacier advanced over moraine ridges during the period 1985-99, small changes in position caused thorough reorganizations of proglacial water and sediment routing. Prior to 1985, $\sim 80 \%$ of fine-grained sediment released from the ice was stored within the moraine complex, but between 1985 and $199930 \%$ of the length margin advanced to the distal side of the moraine, routing its water and sediment output directly into the proglacial river. Major sediment stores such as intra-moraine lake basins were created and destroyed by advances of just a few metres, and the formation and drainage of temporary lakes associated with transitory ice positions caused discharge peaks, episodes of erosion, and destabilization of moraine ridges by piping and slope failure. Changes in hydrology and sediment loading of proglacial streams can thus reflect changes in the geomorphology of the margin rather than changes in glacier mass balance. Distal processes and sediments are predicted to reflect a complex interaction between production and storage, dominated by the relationship of the ice front to its marginal geomorphology. Caution is therefore necessary in reconstructing glacier mass balance, deglaciation chronology or climate change from proglacial sediments and morphosequences (e.g. Visser, 1996), or inferring glacier sediment output from mass-balance data (e.g. Andrews and others, 1994).

\section{GONGLUSION}

The northern margin of Russell Glacier advanced at $\leq 7 \mathrm{ma}^{-1}$ between 1968 and 1999. Changes in ice-margin geomorphology associated with small advances of the glacier across marginal moraines reduced the potential for water and sediment storage between the ice and the moraine, increased the sediment load of proglacial streams, changed the geography of periodically draining lakes and caused changes in water and sediment routing that affected the stability of the moraine. Proglacial hydrology and sediment flux were controlled not only by glacier mass balance but also by evolving ice-marginal geomorphology. Future interaction between the advancing glacier margin, the moraines and the ice-marginal lakes will be a dominant control on sediment supply to the proglacial zone, which must be taken into account when using proglacial sediment records to reconstruct glacier mass balance.

\section{ACKNOWLEDGEMENTS}

Permission to carry out the research was granted by the Danish Polar Centre and the Commission for Scientific Research in Greenland. Fieldwork between 1984 and 1999 was funded by The Royal Society and the U.K. Natural Environment Research Council. Figures were prepared by A. Lawrence and R. Burgess. M. Hambrey, C. Warren and an anonymous referee improved the manuscript.

\section{REFERENGES}

Andrews, J. T., J. D. Milliman, A. E. Jennings, N. Rynes and J. L. Dwyer. 1994. Sediment thicknesses and Holocene glacial marine sedimentation rates in three East Greenland fjords (ca. 68 ${ }^{\circ}$ N). F. Geol., 102(6), 669-683.

Gordon, J. E. 1986. Correspondence. Glacial lake drainage near Søndre Strømfjord, West Greenland. 7. Glaciol., 32(111), 304.

Knight, P. G. and A. J. Russell. 1993. Correspondence. Most recent observations of the drainage of an ice-dammed lake at Russell Glacier, West Greenland, and a new hypothesis regarding mechanisms of drainage initiation. 7. Glaciol., 39(133), 701-703.

Russell, A.J. 1989. A comparison of two recent jökulhlaups from an icedammed lake, Søndre Strømfjord, West Greenland. F. Glaciol., 35(120), 157-162.

Russell, A. J. and C. de Jong. 1988. Lake drainage mechanisms for the icedammed Oberer Russellsee, Søndre Strømfjord, west Greenland. Z Gletscherkd. Glazialgeol., 24(2), 143-147.

Russell, A. J., J. F. Aitken and C. de Jong. 1990. Observations on the drainage of an ice-dammed lake in West Greenland. F. Glaciol., 36(122), 72-74.

Russell, A. J., F. G. M. van Tatenhove and R. S.W. van de Wal. 1995. Effects of ice-front collapse and flood generation on a proglacial river channel near Kangerlussuaq (Søndre Strømfjord), West Greenland. Hydrol. Processes, 


\section{$\mathbf{9}(2), 213-227$.}

Scholz, H., B. Schreiner and H. Funk. 1988. Der Einfluss von Gletscherläufen auf die Schmelzwasserablagerungen des Russell-Gletschers bei Söndre Strömfjord (Westgrönland). Z Gletscherkd. Glazialgeol., 24(1), 55-74.

Sugden, D. E., C. M. Clapperton and P. G. Knight. 1985. A jökulhlaup near Søndre Strømfjord, West Greenland, and some effects on the ice-sheet margin. F. Glaciol., 31 (109), 366-368.

Thomas, R. H., B. M. Csathó, S. Gogineni, K. C. Jezek and K. Kuivinen. 1998. Thickening of the western part of the Greenland ice sheet. F. Glaciol., 44(148), 653-658

VanTatenhove, F. G. M., C. M. Roelfsema, G. Blommers and A. vanVoorden.
1995. Change in position and altitude of a small outlet glacier during the period 1943-1992: Leverett Glacier, West Greenland. Ann. Glaciol., 21, 251-258.

Visser, J. N. J. 1996. A Late Carboniferous subaqueous glacial valley fill complex: fluctuations in meltwater output and sediment flux. S. Afr. F. Geol., 99 (3), 285-291.

Weidick, A. 1991. Present-day expansion of the southern part of the inland ice. Gronl. Geol. Undersogelse. Rapp. 152, 73-79.

Weidick, A., C. E. Bøggild and N. T. Knudsen. 1992. Glacier inventory and atlas of West Greenland. Gronl. Geol. Undersogelse. Rapp. 158.

MS received 27 October 1999 and accepted in revised form 7 March 2000 